\title{
The Spirit of Muslim Culture According to Muhammad Iqbal
}

\author{
Adibah binti Abdul Rahim
}

\begin{abstract}
In the history of civilization, culture and religion have always developed in a close proximity to each other. Indeed, one cannot conceive of development in religion and culture in isolation from each other. It is precisely this unity of culture and religion which is to be the basis of Muhammad Iqbal's views on Muslim culture. Culture, for Iqbal, is the most important factor of sociological life and the basis of its change. In explaining social change, he believed that culture plays a greater role than other factors, such as, economy and politics. Although he has deeply studied the Western thought, Iqbal's views on culture are essentially shaped by the teachings of the Qur'an. This paper tries to explore Iqbal's concept of Muslim culture and its spirit. It does not mainly concern with the determination of what constitutes culture or the enumeration of various traits of Muslim culture. Rather, the paper tries to study Iqbal's critical evaluation of the spirit of Muslim culture and the fundamental principles which motivate, inspire, and direct Muslims in their cultural pursuits.
\end{abstract}

Index Terms-Muslim culture, the concept of self, the concept of society.

\section{INTRODUCTION}

Iqbal's concept of Muslim culture is not confined to geographical, social, and national limitations; rather it includes a very wide scope and embraces all expressions of human activity. For Iqbal, Muslim culture describes comprehensively about the concept of self, the concept of society, and the concept of life as a continuous movement in time. All these concepts are inseparable from each other and have direct bearing on his views on Muslim culture.

\section{IQBAL's CONCEPT OF MUSLIM CULTURE}

The most fundamental aspect of Iqbal's views on Muslim culture is the philosophy of self. This philosophy of self has been found in Iqbal's works in Persian, Asrar-i-khudi and Rumuz-i-bekhudi. Asrar-i-khudi was translated into English version by Professor R. A. Nicholson from Cambridge University under the title the Secrets of the Self. It deals with the philosophy of the self, or the individual personality. Meanwhile, Rumuz-i-bekhudi was translated into English by Professor A. J. Arberry under the title The Mysteries of Selflessness, and it deals with the individual in relation to his society. Then, the philosophy of self has been subsequently developed in all Iqbal's poetical works, and more

Manuscript received May 4, 2014; revised July 7, 2014.

Adibah binti Abdul Rahim is with the International Islamic University Malaysia (IIUM), Kuala Lumpr, Malaysia (e-mail: adibahar@iium.edu.my). systematically in his lectures, the Reconstruction of Religious Thought in Islam. For Iqbal, understanding of the nature of self is essential for understanding of the nature of culture and the principle of its growth. Iqbal regarded self as the basis of the entire organization of life. Self, according to him, is an active and creative force in which a person should strive towards the achievement of a refined personality as well as to participate in the affairs of the universe to suit his highest position as the vicegerent of God on earth. Self is also considered as the centre of all man's activities and actions. Therefore, Iqbal rejected all philosophical and religious schools of thought which inculcated self-negation or self-abandonment and denied the reality of self, and regarded it as a mere illusion not worth striving for. The concept of self- negation considers weakness, laziness and inaction as fascinating things, and it holds a renunciation of the world, escape from the struggle of life, and living in asceticism. These are obviously against the spirit of Islam. Therefore, Iqbal is strongly opposed to the doctrine of self- negation, and he observed that this concept as the main cause for the decline of Muslims nation. The moral and religious ideal of man, according to Iqbal, is not self-negation, but it must be self-assertion or self-realization. Since man is the supreme creation of God, he must realize his inherent ability, power and possibilities for the perfection of his own personality and for the progress of society.

The rise or fall of individuals and nations, according to Iqbal, is due to strengthening or weakening of their self. If the individuals or nations direct their attentions towards realizing and affirming of self, they will become strong and could survive in power and greatness. Meanwhile, if they negate their self, they will become weak. Therefore, man should strengthen the self and bring it to perfection; he should play an active role, act and react purposefully on his environment [1]. In this sense, Iqbal asserted that the self interacts with its material and cultural environment and utilizes it to realize the purpose of man's life as a servant as well as the vicegerent of God. Obviously, Iqbal stressed on active life for the self-development.

Talking about the self-development, Iqbal gave emphasis on the concept of freedom. The freedom of self, according to him, is not absolute in its form; rather it is subject to his responsibility and accountability to God. The inner urge of freedom must be controlled and guided by God under the teachings of Islam as a comprehensive code of life. Therefore, Iqbal saw the activity of self as a directive energy whereby man is free to act in this world under the direction of God. For him, freedom means that man is able to free himself from following his whims and turning himself to God. In this regard, Iqbal considered the obedience and love for God as 
the foremost condition for the right development of self, and that is the early stage of self-development. The last stage of self-development, according to Iqbal, is the vicegerency of man. It is the stage where man played an active role as the vicegerent of God on the earth and would transform the world in accordance with ideals set forth by Islamic teachings.

In his concept of Muslim culture, Iqbal also gave emphasis on the necessary relationship between the spiritual and the material aspects of man's life. To him, the spiritual and material aspects are not two opposing forces, and the affirmation of the spiritual self demands a willing acceptance of the material world with a view to making it an ally in the process of our development. It is only because of the inseparable relationship between the two that man was able to have sharpened his intellect and built up a great culture and civilization. Iqbal frequently used the two important terms in describing the human existence; alam-i anfus (spiritual world) and alam-i afaq (material world) [2]. He criticized both the extreme materialists for denying the reality of alam-i anfus and the extreme idealists who deny the reality of alam-i afaq. He assigned equal value to both in the life and growth of man and so in Muslim culture and civilization, and he rejected the idea of the supremacy of the one over the other.

Another important constituent of Muslim culture is the concept of society. According to Iqbal, individual self has a larger self and that is the society to which he belongs. Iqbal claimed that society is a must for the proper growth and development of human self and it is only in society that man can achieve self-realization and fulfills his missions. Therefore, Iqbal has given an equal importance to the individual and society in cultural developments. A harmonious working of the individual and the society produced a durable human civilization. Both complement and supplement each other in their common struggle to achieve a good civilization. In other words, the individual is the internal and the society is the external manifestation of human civilization. For Iqbal, there is a necessary relationship between the individual and the society, and both contribute mutually to each other's development. The society helps the individual to discipline himself and to realize the best in him while the individual helps society for cultural development. It is in his work Rumuz-i-bekhudi that Iqbal discussed the function of the society and presented the relationship between the individual and cultural life of the society in which he lives, moves and exists. He said;

"Alone he is weak and powerless, his energies are scattered and his minds are narrow, diffuse and indefinite. It is the active and living memberships of a vital community that confers on him a sense of power and makes him conscious of great collective purposes which deeper and widen the scope for the growth of his individual self"'[3].

Iqbal acknowledged that the attachment to a society is a blessing for the individual because it is in society where individuals develop their personalities and attain their perfection. He believed that individuals are basic units of society, and society is instituted and organized through individuals.

Iqbal's concept of society is not narrow and parochial. It is not racial or geographical unity which can form the right basis of people's coherence; rather it is the unity of beliefs and purposes which unite a collection of individuals into a genuine human society. Human culture and civilization is thus a matter of both the ideology inspiring individual and societal conduct and social environment provided for its development. The ideology which inspires both the individual and the society is to be found in the framework provided by religion. Therefore, Iqbal looked at the function of religion in the life of the individual and the society, which gives birth to human culture and civilization. It is in this sense that religion is an integral and inseparable part of human culture and civilization.

Iqbal has laid down some essential requirements for an ideal Muslim society. The most important requirement is that it must be based on the belief in tawhid. For him, tawhid is the soul of society because it generates unity of thought and unity of actions in individuals who are bound together by society. The second important corner-stone for the structure of the ideal Muslim society is faith in prophethood. Iqbal emphasized that the strength and the unity of the Muslim society are based on the adherence to the Qur'an and the practice of the Prophet (p.b.u.h) or sunnah. Thirdly, Muslim society should abide by the code of law, that is, shari'ah. Iqbal identified Muslims' failure to abide by the shari'ah as the primary cause for their decline. Besides a code of law, an ideal society also needs a common centre for all its cultural and social activities. Iqbal emphasized that the unity of a society emanates from this very centre, and its existence can become strong by the strength of this centre. For the Muslims, this centre is provided by the kaabah in Mekah. It helps in maintaining unity of the Muslims and promotes their integration as religious community through a pilgrimage assembly once in a year. The next requirement for an ideal society is that it must have a goal towards which the whole community should strive. For Muslims, the objective is the preservation and propagation of the principle of tawhid. Furthermore, the Muslim society must acquire mastery over the study of science. In fact, Iqbal mentioned another reason for the decadence of Muslims nation is the neglect of science. Last but not least, Iqbal gave emphasis on the importance of safeguarding maternity for the sake of preservation of society. The real wealth of society, according to him, consists in the virtue of children and children's children. Therefore, maternity must be honored.

\section{UNIQUE SPIRIT OF MUSLIM CULTURE}

In order to explain the spirit of Muslim culture, Iqbal highlighted three sources of knowledge mentioned in the Qur'an; the inner experience, nature, and history. These three points become the basis for discussing the unique spirit of Muslim culture.

Under the leadership of the Prophet (p.b.u.h) and the guidance from the Qur'an, Muslim culture guarantees continues progress and betterment in the whole life of man. For Iqbal, religion as a cultural force is primarily functional and practical. He discussed pragmatically to judge the value of religious experience. For him, the Prophet's religious experience has social significance as compared to mystic 
experience. The Prophet (p.b.u.h) returns to normalcy as an active agent of social change and enabled to direct the forces of life and reshape the ends and purposes of individual and societal lives. Meanwhile, the mystic experience is considered as an end in itself, and therefore, his return to normalcy is meaningless for human society. It does end up in his personal accomplishments but does not mean much to mankind at large. Religious experience of the Prophet, however, is meant to completely transform the human world. The Prophet (p.b.u.h) is expected to give society a new direction by citing a new value system so that he is able to pull the society out of stagnation. The return from such an experience is thus creative. For Iqbal, the perfection of human society is not possible without the message of prophethood [4].

In this regard, Iqbal explained the role of the Prophet (p.b.u.h) in establishing a civilized society. He argued that Prophet Muhammad (p.b.u.h) was the greatest human personality; he was a great architect of state, and the legislator of the constitution. Thus, the Prophet (p.b.u.h) was considered as the greatest reformer and the leader in human history in regard to true culture and civilization. The Prophet (p.b.u.h) has left a great spiritual legacy, which guided human civilization throughout many centuries. The legacy of the Prophet (p.b.u.h) had such a great effect in the past and will have a greater effect in the future precisely because he established the religion of truth and laid the foundation of the only civilization which guaranteed the happiness and felicity of man. Therefore, the religion which the Prophet (p.b.u.h) conveyed and the civilization, which he established at his God's command, are inseparable from each other. In fact, the objective of religion, according to Iqbal, was to built up a true civilization and he claimed that a civilization only deserves to be called a true civilization if it can present Islam as a religion it its pure condition [5].

Iqbal showed that the Prophet (p.b.u.h) has brought a great change in the world's history. The Prophet (p.b.u.h) was sent when the Arabs were in a state of ignorance. After the advent of the Prophet (p.b.u.h), the higher principles of social life were inculcated into Arab society. There was a big difference between both the state of people of Arabia prior to the mission of the Prophet (p.b.u.h), and the state of the people under the light of Revelation and prophethood. The Qur'an urged Muslims to avoid the former and follow the letter [6].

Furthermore, it could be observed that there were many revolutionary changes in the life and society of the Arabs, and the change brought by the Prophet (p.b.u.h) was a revolution in the fullest sense of the word. A revolution involves all aspects of life including the personal and the family system. It also covered the military organization where the Prophet (p.b.u.h) was the Commander in chief of the Muslim forces. In the educational system, the Prophet (p.b.u.h) was an ardent advocate of the pursuit of knowledge and education. The search for knowledge was enjoined both by the Qur'an and the Prophet. Furthermore, the Prophet's revolution also focused on the economic system, which was ignored in pre-Islamic Arabia. They never knew of a centralized government, and therefore, had no knowledge of public finance. The Prophet (p.b.u.h) was the first to set up a centralized state and an organized financial system. He was the first to initiate a public treasury in Medina where he established five sources of state revenue systems, namely, zakah, sadaqah, jizyah, kharaj, khums of al-ghanimah, and fayy. They became the five traditional taxes sanctioned by Islam. The most important reform of the Prophet (p.b.u.h) was the unification of the Arabs tribes into a single community based on allegiance to a single religion and a single political centre at Madinah. He built a new political organization called the Ummah. In addition, the state replaced the tribal system of pre- Islamic Arabia.

In this sense, Iqbal did not only emphasize the individual spiritual role of the Prophet, but also stressed on his relation to the Ummah in bringing about a world of governance. The Prophet (p.b.u.h) did not only possess a purely religious or mystic experience, but was also as an active agent of social change who directed the forces of life and shaped the ends and purposes of individual and collective life.

Another point stressed by Iqbal was the significance of the ending of the prophethood in which he considered some great cultural values in it. To him, the ending of prophethood to be a milestone in the history of Muslim culture in particular and in the history of the mankind in general because it has actually laid a firm foundation for the cultural advancement of Islam so as to keep it abreast with the changing times. According to Iqbal, the ending of prophethood means maturity of mankind and the birth of inductive reason.

Iqbal explained that the ending of prophethood generates an independent and uninhibited attitude towards life. It is to make man fully responsible for his action and to find solutions for his problems through his own efforts. It promotes enquiry based on reason, thus, opening up new vistas of knowledge and action. In this sense, Iqbal observed the beginning of a new era for man- a transition from his blind dependence on divine guidance to his independence and freedom of action by using his own intellect. It is this spirit of rationality which led Iqbal to place Prophet Muhammad (p.b.u.h) between the ancient and the modern world; the source of his revelation representing his connection with the ancient world and the spirit of his revelation portraying him to be the initiator of the modern worlds. Iqbal said 'in so far as the source of his revelation is concerned, the Prophet (p.b.u.h) belongs to the ancient world, and in so far as the spirit of his revelation is concerned, he belongs to the modern world'. In this regard, Iqbal regarded the ending of the prophethood as a culmination of an evolutionary process of human intellect, and he identified this functional point between the ancient and the modern world as 'the birth place of inductive intellect'.

Obviously, Iqbal emphasized that the Prophet (p.b.u.h) had left the great cultural legacy of Islam in terms of flourishing the spirit of rationality. After the death of the Prophet (p.b.u.h), a transition took place from blind dependence of men on Divine guidance to their dependence on their own intellect and freedom of action. This has been regarded as the culmination of the evolutionary process of the human intellect. Therefore, Iqbal regarded the spirit of the Prophet's Revelation to be the initiator of the modern world. Under the leadership of the Prophet (p.b.u.h) and the guidance from the Qur'an, the Muslim culture and civilization continues providing a good life of man. 
In addition, Iqbal mentioned two other sources of knowledge, nature and history which are emphasized by the Qur'an, and which have a direct bearing on the reflection of Muslim culture. Iqbal claimed that the cultural development of a Muslim society depends upon how these two sources of knowledge are tapped.

Iqbal explained that Islam promotes a dynamic conception of the nature and rejects the static views of it. For him, the spirit of Muslim culture is based on the axiom that knowledge must be based on factual and the concrete. It is the intellectual capture of and power over the concrete that makes it possible for the intellect of man to pass beyond the concrete. Knowledge then must be developed by the method of observation and experiment. The Qur'an itself emphasizes on the experimental method because God repeatedly commands human beings to apply reason, to think, to use their eyes and ears, and so on. This means Muslims, through their sense perception, should evolve empirical science. The Qur'an, according to Iqbal, could not have been studied with the speculative method of Greek philosophy; rather it had to be based on factual and concrete.

As compared to Hellenic stress on conceptualism and abstractionism, the Qur'an preached a practical and a pragmatic approach towards life. This spirit inevitably brought Muslim thought into conflict with Greek philosophy, thereby making Muslims revolt against it. Iqbal brought out the essential differences that exist between two cultures in almost all departments of knowledge [7]. For example, he pointed out the extent to which Aristotelian logic was subjected to criticism by Ibn Sina, Nazzam, Ibn Taymiyyah and Ibn Hazm. He also highlighted al-Kindi's discovery that sensation was proportionate to the stimulus. These are a few examples of the Muslim scholars' revolt against the Greek philosophers. In this sense, Iqbal tried to eradicate the misunderstanding that the character of Muslim culture was determined by Greek thought.

Iqbal emphasized that Muslims' contributions in the realm of knowledge cannot be distorted and belittled. He claimed that it was Muslims who developed the experimental method and laid the foundations of empirical sciences. Europe took those empirical sciences from the Muslims and developed them further into what is known now as modern science and technology. In this sense, Iqbal believed that Muslims were the original founders of various sciences during the flourishing of Islamic civilization.

Obviously, the study of the history of science would reveal that in the early stages of the empirical sciences, the names of Muslim scientists occurred frequently. Even today, the true origins of some of these sciences are still acknowledged and retained their Arabic names. For instance, algebra, a branch of mathematics, still remains the same name; as well as the term chemistry, which was derived from the Arabic word al-kimiya. Iqbal fully appreciated the contribution of Muslim scholars in various sciences and disciplines which initiated the great Islamic culture and civilization. However, it is observed that Muslims do not give fully recognition, and many Muslim still reluctant to identify themselves with their own culture and civilization. Very few among the Muslim intellectuals engage themselves with the philosophical texts of Muslim philosophers and scientists.

\section{CONCLUSION}

Iqbal's idea of self has been examined since he claimed that understanding of self is essential for an understanding of the nature of culture and the principle of its growth. He is fully aware that the doctrine of self- negation has crept into and colored Muslim thought although it is essentially inconsistent with the spirit of Islam. As opposed to some religious and philosophical schools of thought which belittled the reality of self and regarded it as a mere illusion of mind and not possessing any abiding significance of its own, Iqbal has brought to us an awareness of the actual significance of the self. For him, self is a real and pre-eminently significant entity, which is the centre and basis of the entire organization of human life. Based on his idea of self-assertion or self-realization, Iqbal made an attempt to interpret the reality of life in terms of human will and action. By preaching the fullest affirmation of the self in this real world of forces, Iqbal tried to give a dynamic quality of the Muslims' thought and conduct.

Furthermore, Iqbal hold that the development of an active individuality is impossible except in contact with a societal environment. Therefore, he has given an equal importance to the individual and society in the development of Muslim culture. Iqbal was fully aware of the value of a society's culture for the right development of the individual. The continuity of cultural life of a society depends on the part of its members bringing both a genuine appreciation and a critical appraisal of its cultural values and traditions. They must have the capacity for active understanding, assimilation and reconstruction of the existing culture.

In addition, Iqbal drew on three sources of knowledge mentioned in the Qur'an; inner experience, nature, and history in his discussion about the spirit of Muslim culture. To bring out the real spirit of Muslim culture, according to Iqbal, Muslim thinkers should not refer to the speculative nature of Greek philosophy which enjoyed theory and neglected facts. The spirit of Muslim culture is based on the concrete and finite. He firmly believed that the birth of the method of observation and experiment in Islam is not due to a compromise with Greek thought but to a prolonged intellectual warfare with it. Iqbal called this an intellectual revolt against Greek philosophy.

\section{ACKNOWLEDGMENT}

I would like to express my gratitude to the Kulliyyah of Islamic Revealed Knowledge and Human Sciences, International Islamic University Malaysia (IIUM) for sponsoring me to present this paper in the $3^{\text {rd }}$ International Conference on Knowledge, Culture and Society (ICKCS 2014) which is held in Singapore.

\section{REFERENCES}

[1] I. Muhammad, The Reconstruction of Religious Thought in Islam, Stanford/London: Stanford University Press, 2012, p. 102.

[2] S. H. M. Jafri, "Iqbal and human civilization," Hamdard Islamicus, vol 7, no. 1, p. 46.

[3] K. G. Saiyidin, Iqbal's Educational Philosophy, $8^{\text {th }}$ ed, Sh Muhammad Ashraf, Lahore, 1977, p. 56.

[4] I. Saeeda, "Islamic rationalism in the sub-continent: with special reference to shah Waliullah," in Islamic Book Services, S. A. Khan and A. M. Iqbal, Lahore, 1984, p. 323. 
[5] M. F. Wajdi, Al-Islam fi 'Asr, Bayrut: Dar al-Kitab al-Arabi, p. 220 , 1967.

[6] Y. A. Abdullah, The Meaning of the Holy Qur'an, Brentwood, Maryland: Amana Corporation, p. 264, 1995.

[7] R. Bertrand, A History of Western Philosophy and Its Connection with Political and Social Circumstances from the Earliest Times to the Present Day, Lahore: Routledge, p. 173, 1970.

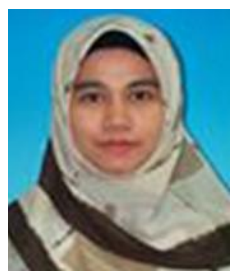

Adibah binti Abdul Rahim was born at Terengganu, in 1971. She obtained her Ph.D. in Islamic revealed knowledge and heritage from International Islamic University Malaysia (IIUM) in 2004. She started her career as an assistant lecturer, and was appointed as a lecturer after completing her master degree. She is currently working as an assistant professor in Kulliyyah of Islamic revealed knowledge and human sciences (IRKHS), IIUM.

In 2008, she has been appointed as a visiting academic at Monash University, Victoria, Australia during her accomplishment of sabbatical leave. Dr. Adibah was appointed as a project leader for building taxonomy on Usul al-din, philosophy, and comparative religion for IIUM library. She was also appointed as principal of residential college in IIUM. Her academic area of interest is contemporary Islamic thought, and she has presented papers at local and international meetings on this area.

Dr. Adibah wrote various articles and among them are Muhammad Farid Wajdi's discourse on integration of religion and science, in Islamic Revealed Knowledge and Dimensions of Islamic Thought (Kuala Lumpur, IIUM Press 2010), The Impact of Secularism on Muslims Beliefs and Practices, Journal of Islam in Asia, vol. 7, no. 2 (2010), Major Trends of Muslim Responses to the Challenges of Modernity, Journal of Islam in Asia, special issue, no. 1, March 2011, and many more. 